\title{
A silicified tommotiid from the lower Cambrian of Greenland
}

\author{
CHRISTIAN B. SKOVSTED
}

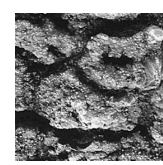

\begin{abstract}
Three specimens of a new eccentrothecimorph tommotiid are described from the Paralleldal Formation of North Greenland. The specimens are all tubular structures composed of a number of individual sclerites. The sclerites were arranged in rings, which fused to form a rigid tube during ontogeny. The tube has a basal aperture presumably allowing attachment to a hard substrate. In morphology, both individual sclerites and the tubular scleritome are remarkably similar to specimens of Eccentrotheca from South Australia. However, the Greenland specimens are silicified and may have been either weakly mineralised or calcareous in original composition. In this respect they differ from all previously known tommotiids, considerably expanding the ultrastructural disparity of the Tommotiida and allowing comparison to a new range of possible lophotrochozoan fossils. - Keywords: Small Shelly Fossils, Tommotiida, eccentrothecimorph, Brachiopoda, silicification, Greenland.
\end{abstract}

Skovsted, C.B. 2016. A silicified tommotiid from the lower Cambrian of Greenland. Bulletin of Geosciences 91(3), 553-559 (3 figures, 1 table). Czech Geological Survey, Prague. ISSN 1214-1119. Manuscript received March 22, 2016; accepted in revised form October 4, 2016; published online November 11, 2016; issued November 25, 2016.

Christian B. Skovsted, Department of Palaeobiology, Swedish Museum of Natural History, Box 50007, SE-104 05 Stockholm, Sweden; christian.skovsted@nrm.se

The earliest skeletal fossils from the terminal Ediacaran and early Cambrian are exemplified by tubes, cap-shaped shells and irregular or cone-shaped fossils that are commonly united under the heading Small Shelly Fossils (SSF's; Bengtson 2004). These fossils represent the oldest known undoubted metazoan fossils and likely include early representatives of the stem lineages of modern phyla (Budd 2003, Kouchinsky et al. 2012). One group among the SSF's that have recently attracted considerable attention is the tommotiida. These cap- or cone-shaped fossils are interpreted to be components (sclerites) of multi element external skeletons (scleritomes; Landing 1984). Based on recently discovered tommotiids from South Australia (Skovsted et al. 2008, 2009a, b, 2011, 2015b; Holmer et al. 2008; Balthasar et al. 2009; Larsson et al. 2014), tommotiids have been interpreted to be basal members of the stem group leading to the lophophorate phyla Brachiopoda and Phoronida. This interpretation was based both on the morphology of their tubular scleritome structure (Skovsted et al. 2008, 2009b, 2011; Holmer et al. 2008) and the remarkable similarities in ultrastructure between tommotiids and the earliest brachiopods (Balthasar et al. 2009; Murdock et al. 2012, 2014; Larsson et al. 2014).

In the present contribution I will show that although tommotiids have been thought to be exclusively organophosphatic by original composition (Balthasar et al.
2009), silicified specimens from the Cambrian of North Greenland indicate that the range of mineralogical ultrastructures available to tommotiids may have been larger. This observation, and recently presented evidence that not all tommotiids may have had tubular scleritomes (Skovsted et al. 2015a), strengthens suggestions that the evolution of the lophophorate stem group was more complex than previously imagined (Murdock et al. 2014, Zhang et al. 2014). The new material also opens up new avenues for future research into the distribution, structure and affinity of Small Shelly Fossils.

\section{Material and methods}

The new material from North Greenland includes a single isolated, 3-dimensional specimen and two partly isolated specimens still attached to silicified limestone surfaces. All specimens were recovered from hydrochloric acid residues derived from silicified, cherty limestones of the Paralleldal Formation in central Peary Land (GGU sample 274907; $82^{\circ} 17^{\prime} \mathrm{N} 31^{\circ} 9.2^{\prime} \mathrm{W}$; see also Larsson et al. 2009 for details). The associated fauna includes calcareous brachiopods (Popov et al. 1997), trilobites (Blaker \& Peel 1997, Stein \& Peel 2008), molluscs (Atkins \& Peel 2004, 2008) and the problematic sclerites of Trachyplax (Larsson et al. 
Table 1. Length, width and number of sclerite rings of all specimens of the Greenland eccentrothecimorph. Length and width measurements in $\mathrm{mm}$.

\begin{tabular}{lrrrr}
\hline Specimen & Figure & Length & Width & Rings \\
\hline SMNH X5786 & 2 & 7.5 & 7.2 & 4 \\
SMNH X5787 & 3 & 5.4 & 5.9 & 4 \\
SMNH X5788 & 4 & - & 8.2 & $2 ?$ \\
\hline
\end{tabular}

2009). The preserved fauna, and the presence of archaeocyathans (Debrenne \& Peel 1986) and Salterella Billings, 1861 (Peel \& Yochelson 1982) in overlying rocks, indicates a Cambrian Stage 4 age for the fossiliferous horizon.

The two specimens on silicified limestone surfaces were photographed after coating with ammonium chloride at Uppsala University and the single isolated specimen was gold-coated and pictured using SEM at the Swedish Museum of Natural History. All specimens are housed in the palaeontological collections of the Swedish Museum of Natural History in Stockholm (acronym SMNH).

\section{Silicified eccentrothecimorph tommotiid from North Greenland}

\section{Morphology}

All three specimens are tubular structures with a roughly circular cross-section and a diameter of about $6-8 \mathrm{~mm}$ (Table 1). The length of the specimens is about 5-8 mm, although the terminations probably represent broken margins. All specimens are composed of multiple sclerites that appear to have been fused during growth of the animal. No isolated sclerites were recovered, potentially due to difficulties in identifying such sclerites among the silicified skeletal debris.

The individual sclerites composing the Greenland eccentrothecimorph tubes are elongate oval to sub-rectangular in outline (Figs 1,2). In the completely isolated specimen SMNH X5786 the borders between sclerites are formed by narrow furrows (Fig. 1G-I) while the sclerites in specimen SMNH X5787 are separated by wider and deeper furrows (Fig. 2). Individual sclerites are less easy to identify in the poorly preserved specimen SMNH X5788 (Fig. 3). The sclerite surface is generally not well enough preserved to expose fine details but in SMNH X5786 faint furrows running more or less parallel to the boundaries be- tween sclerites indicate broad growth increments (Fig. 1G). In lateral profile the sclerites of SMNH X5786 are high, conical with height approximately equal to width (Fig. 1H). The apices of all sclerites are inclined towards the same end of the tube. Internally, all sclerites appear to have a shallow cavity (Fig. 1J).

In specimen SMNH X5786 sclerites are clearly arranged in transverse rings that can be followed around most of the circumference of the tube (Fig. 1A-C) although one side of the tube is too poorly preserved to allow sclerites or sclerite rings to be determined (Fig. 1D). The borders between rings are much deeper than between individual sclerites within the rings, suggesting that the sclerites within each ring were amalgamated prior to fusion of the rings (Fig. 1A, B). Although sclerites in specimens SMNH X5787 and SMNH X5788 appear to be arranged in a similar manner, the less perfect preservation of these specimens does not allow detailed definitions of sclerite rings (Figs 2, 3).

In transverse section, specimen SMNH X5786 is close to circular (Fig. 1E) and the transversely embedded specimen SMNH X5788 appears to have a similar circular cross section (Fig. 3) while specimen SMNH X5787 is too deeply embedded in the silicified limestone to reveal the cross-section of the tube (Fig. 2). The diameter of the tube does not appear to change very much along the length of the tube sections. However, in SMNH X5786 the sclerites of successive rings are inclined towards the same end of the tube, and the opposing end show a distinct depressed oval aperture, potentially representing an attachment scar (Fig. 1D-F). The aperture is oblique in relation to the long axis of the tube and appear to cut across two or three sclerite rings, although this is difficult to establish as this side of the tube is relatively poorly preserved (Fig. 1D).

\section{Preservation}

The recovered specimens from North Greenland are derived from silicified limestone samples which also contain brachiopods, trilobites, mollusks and problematic sclerites that have been preserved through silicification of originally calcareous shells (Popov et al. 1997; Blaker \& Peel 1997; Atkins \& Peel 2004, 2008; Stein \& Peel 2008; Larsson et al. 2009). The eccentrothecimorph specimens described here do not appear to differ in any substantial way from co-occurring calcareous brachiopods or molluscs in terms

Figure 1. Eccentrothecimorph tommotiid SMNH X5786, from the Paralleldal Formation, central Peary Land, North Greenland. Specimen isolated from limestone by hydrochloric acid. $\bullet$ A-D - four different lateral views. $\bullet$ E - oblique apertural view. $\bullet$ F - apertural view. $\bullet$ G - detail of A showing growth bands of individual elongate sclerites. $\bullet \mathrm{H}$ - detail of B showing arrangement of sclerites in rings. $\bullet \mathrm{I}-$ lateral view of A showing sclerites in successive rings inclined away from basal aperture. $\bullet \mathrm{J}$ - internal view of one sclerite close to abapical margin. Scale bar equals 5 mm in A-F. Scale bar in $\mathrm{G}-\mathrm{J}$ equals $1 \mathrm{~mm}$. 


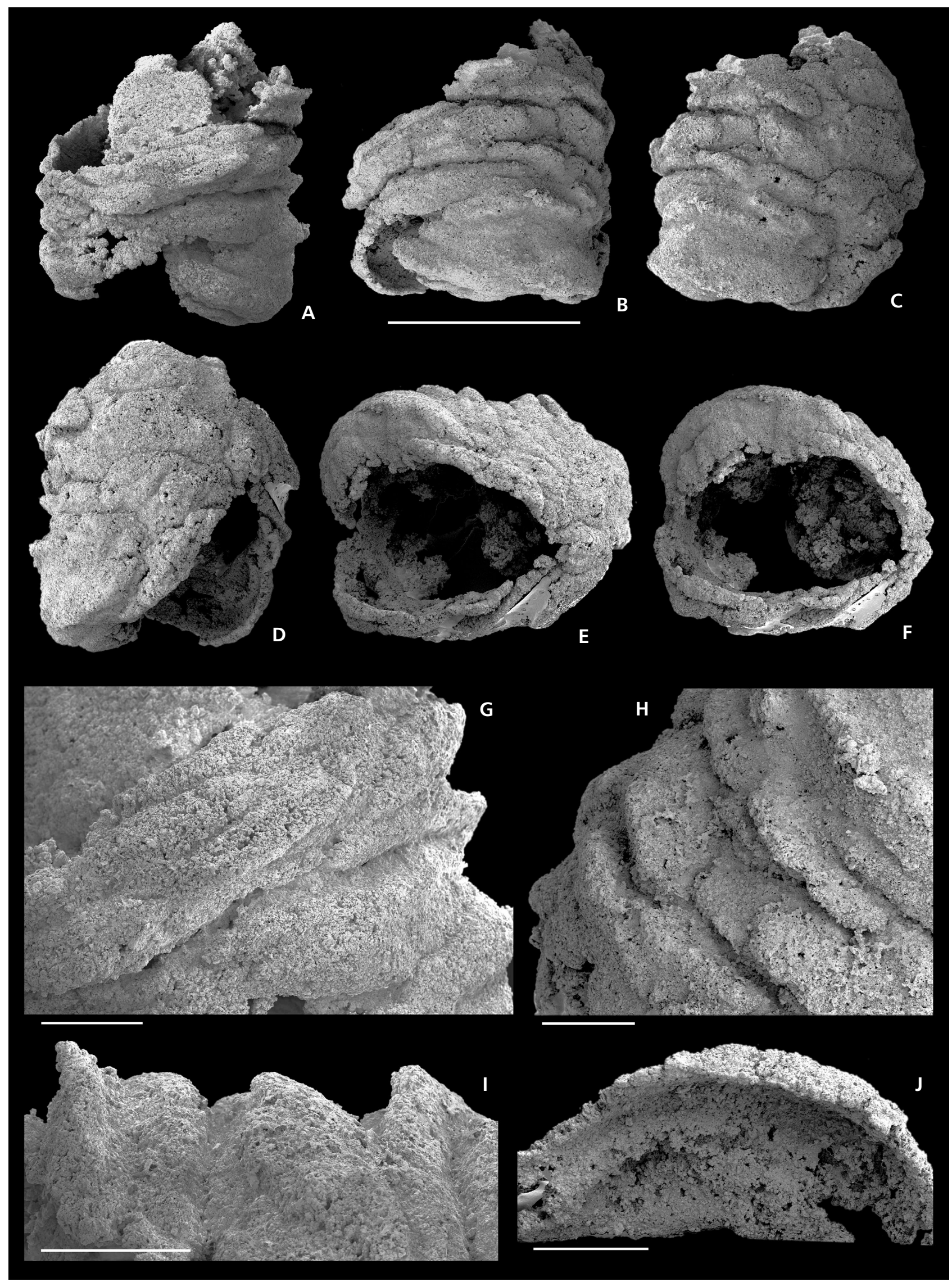




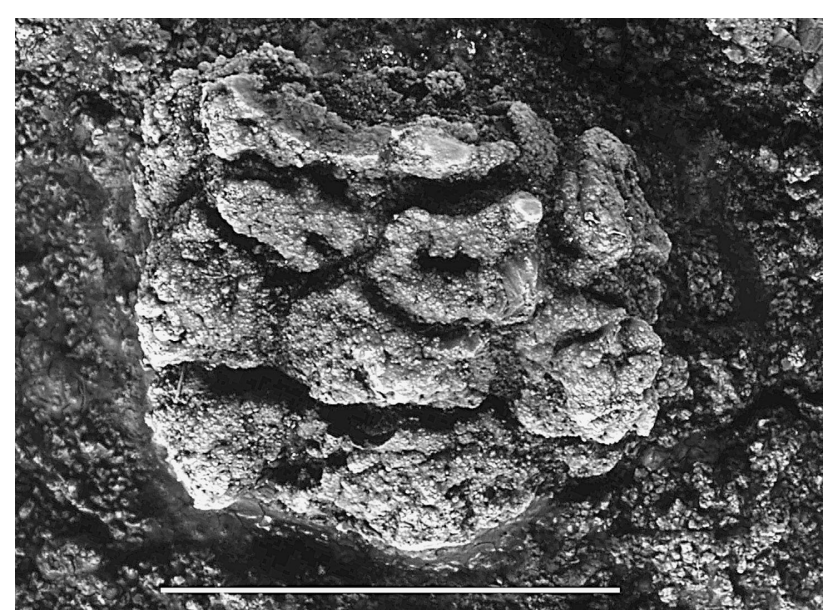

Figure 2. Eccentrothecimorph tommotiid SMNH X5787, from the Paralleldal Formation, central Peary Land, North Greenland. Lateral view of specimen partly embedded in silicified limestone. Scale bar equals $5 \mathrm{~mm}$.

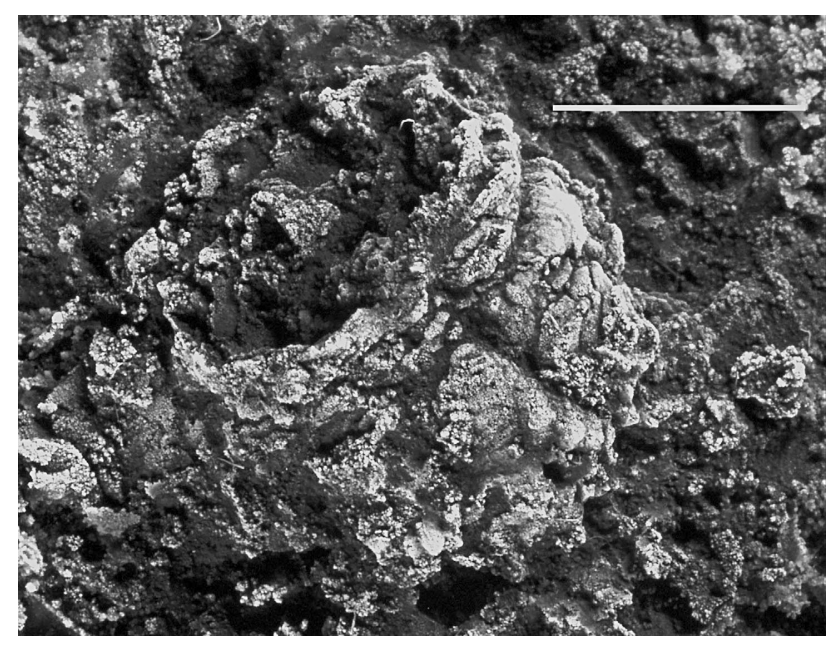

Figure 3. Eccentrothecimorph tommotiid SMNH X5788, from the Paralleldal Formation, central Peary Land, North Greenland. Specimen obliquely embedded in silicified limestone. Scale bar equals $5 \mathrm{~mm}$.

of preservation and have also been silicified. The preparation process, using hydrochloric acid would have destroyed any non-silicified fossils in the sample but preparation of a sub-sample in acetic acid did not result in discovery of any phosphatic fossils (J.S. Peel, personal communication 2015).

In general, the process of silicification appears to most readily affect calcitic fossils (Shubert et al. 1997, Baliński 1999) and when originally phosphatic hard parts, such as vertebrate remains, conodonts or lingulid brachiopods are present in silicified marine faunas of the Paleozoic, they are usually not affected by silicification (Baliński 1999, Sun \& Baliński 2008). Indeed, the formation of silicified nodules has even been interpreted to facilitate exceptional preservation of phosphatic shell structures in lingulid brachiopods (Zabini et al. 2012).
A few reports of originally phosphatic brachiopod shells and tommotiid sclerites from the Cambrian, partly replaced by silica have been published (Balthasar 2004, 2007, 2008; Skovsted et al. 2009a; Holmer et al. 2009). In the majority of these cases silicified parts of shells appear to have originally been weakly mineralised and first replaced by calcite before silicification of this secondary calcite (Balthasar 2004, 2007, 2008; Skovsted et al. 2009a). Exceptional opalization of marine vertebrate bone has also been suggested to be a secondary process after calcite replacement of original phosphate material (Pewkliang et al. 2008). The exception to this pattern is in the cryptotretid brachiopod Salanygolina Ushatinskaya, 1987 from the early Cambrian of Mongolia, where the external surface and parts of the shell interior appear to have been silicified without prior replacement by calcite (Holmer et al. 2009). Despite this example, wholesale replacement of phosphatic shells by silica appears to be exceedingly rare. Consequently, it is unlikely that the original shell mineralogy of the Greenland specimens described here was organophosphatic. Presumably, the shell material of the sclerites could have been poorly mineralised, but the apparent lack of deformation of the isolated tubular specimen SMNH X5786 would suggests considerable rigidity, and a more likely interpretation is that the sclerites may have been originally mineralised by calcium carbonate.

\section{Interpretation and identification}

In general morphology the silicified tubular specimens are closely comparable to tubular specimens of Eccentrotheca helenia Skovsted et al., 2011 from the Arrowie Basin of South Australia (Skovsted et al. 2008, 2011). This tommotiid exhibits a highly variable scleritome structure with tubular or cone-shaped structures composed of fused sclerites arranged in rings that appear to have coalesced to form a tube during growth, exactly as in the Greenland specimens described here. Individual sclerites in the tubular specimens of E. helenia are variable in morphology and include both broad, cap-shaped sclerites and narrowly compressed conical sclerites, again very similar to the Greenland specimens. The tubes of E. helenia exhibit a distinct aperture (usually at the narrow end of cone-shaped specimens and sometimes inclined to the long axis of the tube), presumably reflecting attachment to a hard substrate (Skovsted et al. 2011). A similar aperture is evident in the best preserved of the Greenland specimens (Fig. 1D). However, the tubular specimens of E. helenia from Australia are substantially smaller than the Greenland specimens (maximum diameter not exceeding $3 \mathrm{~mm}$; Skovsted et al. 2011 compared to over $8 \mathrm{~mm}$ in the Greenland specimens) and individual sclerites also appear to be smaller. The same applies to the sclerites of E. kanesia Landing et al., 1980 from 
the Terreneuvian of Avalonia (Landing et al. 1980; Landing 1988, 1991, 1995) and the related tommotiid Kulparina Conway Morris in Bengtson et al., 1990 from South Australia which are also known to have had a tubular scleritome (Skovsted et al. 2011, 2015b). Paterimitra Laurie, 1986 from South Australia may include sclerites of similar size as in the Greenland specimens, but these exhibit characteristic pyramidal morphologies not obvious in the Greenland material.

Based on the close similarity in morphology of individual sclerites and in the tube construction, the Greenland specimens would appear to represent a tommotiid species closely related to Eccentrotheca helenia and it seems quite clear that the specimens represent an eccentrothecimorph tommotiid. However, the small number of specimens available and the peculiar preservation and uncertain (possibly calcareous) original composition of the Greenland specimens presently precludes identification at the generic level.

\section{Conclusions}

The suggestion that the Greenland eccentrothecimorph specimens may have been originally calcareous in composition is clearly at odds with the previous hypothesis that all tommotiids were organophosphatic (Landing 1984, Balthasar et al. 2009, Skovsted et al. 2009a). However, Cambrian fossils with non-mineralised or calcareous sclerites of comparable size and morphology to the Greenland specimens are known. The fauna of the Paralleldal Formation in central Peary Land includes abundant sclerites of the possible multiplacophoran mollusk Trachyplax (Larsson et al. 2009) co-occurring with the new eccentrothecimorph. Trachyplax exhibit a number of quite distinctive sclerite morphologies (Larsson et al. 2009) and although its scleritome structure remain unknown, no direct comparison between Trachyplax and eccentrothecimorph tommotiids can be made. The problematic fossil Cotyledion Luo et al., 1997 from the Chengjiang fauna of Yunnan Province in South China, recently redescribed as a stem group entoproct (Zhang et al. 2013), represents another early Cambrian taxon with somewhat similar sclerites. Cotyledion, which may belong to the same total group as eccentrothecimorph tommotiids, exhibits a large number of rounded oval or rectangular sclerites covering its narrow stalk and wide calyx. As noted by Zhang et al. (2013), the sclerites are not arranged in transverse rings but rather in longitudinal files and do not appear to fuse to form larger composite sclerites like in eccentrothecimorphs. However in other respects the scleritome construction of Cotyledion, particularly in the stem, can be compared to the scleritome construction of the tommotiid Eccentrotheca and the non-mineralised or calcareous composition of the sclerites appear comparable to the new Greenland eccentrothecimorph (Zhang et al. 2013).

Based on the close comparison in morphology and shell structure, it has been suggested that different brachiopod groups evolved from different tommotiid lineages (Skovsted et al. 2009b) and that calcareous shell mineralogy in brachiopods evolved secondarily from phosphatic bivalved ancestors (Balthasar et al. 2009). However, the find of tommotiids with calcareous sclerites suggests that transitions from phosphatic to calcareous shell mineralogy could have happened earlier in tommotiid-brachiopod evolution than previously thought. The extremely close morphological similarity between the (phosphatic) Eccentrotheca from Australia and Avalonia and the new (calcareous?) eccentrothecimorph from Greenland further indicates that such transitions in early Cambrian biomineralising taxa could have been much more frequent than assumed.

In summary, the new tubular specimens from Greenland appear to show that the disparity of eccentrothecimorph tommotiids in the Cambrian may have been larger than previously imagined and include forms that were calcareous in original composition or weakly mineralised. It is not inconceivable that calcareous or weakly mineralised cap-shaped sclerites of eccentrothecimorph type were more widely distributed in early lophotrochozoans than hitherto appreciated, as exemplified by the new Greenland tommotiid and the stem entoproct Cotyledion and more such sclerites may in the future be identified in SSF assemblages.

The relationship of these sclerite-bearing tubular fossils to tubiculous fossils such as Cambrocornulithus Yang et al., 2013 and calcareous Paleozoic tubeworms such as tentaculitids and cornulitids (Vinn \& Mutvei 2009, Taylor et al. 2010) or the Ediacaran fossil Namacalathus Grotzinger et al., 2000 (Zhuravlev et al. 2015), all of which have recently been suggested to represent lophophorates, is at present uncertain. However, the discovery of silicified tommotiids will open new avenues to study this enigmatic fossil group in the future and may allow more broad comparisons to other biomineralising lophotrochozoans.

\section{Acknowledgements}

John S. Peel (Uppsala) generously supplied the silicified specimens and photographs of the two specimens embedded in silicified limestone. Timothy P. Topper (Durham) and Uwe Balthasar (Plymouth) are thanked for valuable discussions on tommotiid morphology and shell structures. Guoxiang Li (Nanjing) and one anonymous reviewer are thanked for insightful and constructive reviews. Financial support from the department of Palaeobiology at the Swedish Museum of Natural History is gratefully acknowledged. 


\section{References}

Atkins, C.J. \& Peel, J.S. 2004. New species of Yochelcionella (Mollusca: Helcionelloida) from the Lower Cambrian of North Greenland. Bulletin of the Geological Society of Denmark 51, 1-9.

AtKins, C.J. \& PeEL, J.S. 2008. Yochelcionella (Mollusca, Helcionelloida) from the lower Cambrian of North America. Bulletin of Geosciences 83, 23-38. DOI 10.3140/bull.geosci.2008.01.023

BALIŃSKI, A. 1999. Brachiopods and conodonts from the Early Carboniferous of South China. Acta Palaeontologica Polonica 44, 437-451.

Balthasar, U. 2004. Shell structure, ontogeny, and affinities of the Lower Cambrian bivalved problematic fossil Mickwitzia muralensis Walcott, 1913. Lethaia 37, 381-400. DOI 10.1080/00241160410002090

Balthasar, U. 2007. An Early Cambrian organophosphatic brachiopod with calcitic granules. Palaeontology 50, 1319-1325. DOI 10.1111/j.1475-4983.2007.00729.x

Balthasar, U. 2008. Mummpikia gen. nov. and the origin of calcitic-shelled brachiopods. Palaeontology 51, 263-279. DOI 10.1111/j.1475-4983.2008.00754.x

Balthasar, U., Skovsted, C.B., Holmer, L.E. \& Brock, G.A. 2009. Homologous skeletal secretion in tommotiids and brachiopods. Geology 37, 1143-1146. DOI 10.1130/G30323A.1

Bengtson, S., Conway Morris, S., Cooper, B.J., Jell, P.A. \& RunNEgar, B.N. 1990. Early Cambrian fossils from South Australia. Memoirs of the Association of Australasia Palaeontologists 9, 1-364.

BiLlings, E.H. 1861. On some new or little known species of lower Silurian fossils from the Potsdam Group (Primordial zone). Palaeozoic fossils, Vol. 1, No. 1. Canadian Geological Survey, Dawson Brothers, Montreal.

BlakeR, M.R. \& PeEL, J.S. 1997. Lower Cambrian trilobites from North Greenland. Meddelelser om Grønland, Geoscience 35, $1-145$.

Debrenne, F. \& Peel, J.S. 1986. Archaeocyatha from the Lower Cambrian of Peary Land, central North Greenland. Rapport Grønlands Geologiske Undersøgelse 132, 39-50.

Grotzinger, J.P., Watters, W. \& Knoll, A.H. 2000. Calcified metazoans in thrombolite-stromatolite reefs of the terminal Proterozoic Nama Group, Namibia. Paleobiology 26, 334-359.

DOI 10.1666/0094-8373(2000)026<0334:CMITSR>2.0.CO;2

Holmer, L.E., Pettersson Stolk, S., Skovsted, C.B., Balthasar, U. \& Popov, L.E. 2009. The enigmatic Early Cambrian Salanygolina - a stem group of rhynchonelliformchileate brachiopods? Palaeontology 52, 1-10. DOI 10.1111/j.1475-4983.2008.00831.x

LANDING, E. 1984. Skeleton of lapworthellids and the suprageneric classification of tommotiids (Early and Middle Cambrian phosphatic problematica). Journal of Paleontology 58, 1380-1398.

LANDING, E. 1988. Lower Cambrian of Eastern Massachusetts:
Stratigraphy and small shelly fossils. Journal of Paleontology 62, 661-695.

LANDING, E. 1991. Upper Precambrian through Lower Cambrian of Cape Breton Island: faunas, paleoenvironment and stratigraphic revision. Journal of Paleontology 65, 570-594. DOI 10.1017/S0022336000030675

LANDING, E. 1995. Upper Placentian-Branchian Series of mainland Nova Scotia (middle-upper Lower Cambrian): faunas, paleoenvironments, and stratigraphic revision. Journal of $\mathrm{Pa}$ leontology 69, 475-495. DOI 10.1017/S0022336000034879

Landing, E., Nowlan, G.S. \& Fletcher, T.P. 1980. A microfauna associated with Early Cambrian trilobites of the Callavia Zone, norther Antigonish Highlands, Nova Scotia. Canadian Journal of Earth Sciences 17, 400-418. DOI 10.1139/e80-038

LARsson, C.M., PeEl, J.S. \& HöGSTRÖM, A.E.S. 2009. Trachyplax arctica, a new multiplated problematic fossil from the lower Cambrian of North Greenland. Acta Palaeontologica Polonica 54, 513-523. DOI 10.4202/app.2009.0026

Larsson, C.M., Skovsted, C.B., Brock, G.A., Balthasar, U., Topper, T.P. \& Holmer, L.E. 2014. Paterimitrapyramidalis from South Australia: scleritome, shell structure and evolution of a lower Cambrian stem group brachiopod. Palaeontology 57, 417-446. DOI 10.1111/pala.12072

Laurie, J.R. 1986. Phosphatic fauna of the Early Cambrian Todd River Dolomite, Amadeus Basin, central Australia. Alcheringa 10, 431-454. DOI 10.1080/03115518608619151

Luo, H., Hu, S. \& CHEN, L. 1999. Early Cambrian Chengjiang Fauna from Kunming Region, China. Yunnan Science and Technology Press, Kunming, China. [in Chinese]

Murdock, D.J.E., Bengtson, S., Marone, F., Greenwood, J.M. \& Donoghue, P.C. 2014. Evaluating scenarios for the evolutionary assembly of the brachiopod body plan. Evolution \& Development 16, 13-24. DOI 10.1111/ede.12059

Murdock, D.J.E., Donoghue, P.C.J., Bengtson, S. \& Marone, F. 2012. Ontogeny and microstructure of the enigmatic Cambrian tommotiid Sunnaginia Missarzhevsky, 1969. Palaeontology 55, 661-676. DOI 10.1111/j.1475-4983.2012.01131.x

Peel, J.S. \& Yochelson, E.L. 1982. A review of Salterella (Phylum Agmata) from the Lower Cambrian in Greenland and Mexico. Rapport Grønlands Geologiske Undersøgelse 108, 31-39.

Pewkliang, B., Pring, A. \& Brugger, J. 2008. The formation of precious opal-Clues from the opalization of bone. The Canadian Mineralogist 46, 139-149.

DOI 10.3749/canmin.46.1.139

Popov, L., Holmer, L.E., Rowell, A.J. \& Peel, J.S. 1997. Early Cambrian brachiopods from North Greenland. Palaeontology 40, 337-354.

Schubert, J.K., KidDER, D.L. \& ERwin, D.H. 1997. Silica-replaced fossils through the Phanerozoic. Geology 5, 1031-1034.

DOI 10.1130/0091-7613(1997)025<1031:SRFTTP>2.3.CO;2

Skovsted, C.B., Balthasar, U., Brock, G.A. \& Paterson, J.R. 2009a. The tommotiid Camenella reticulosa from the early Cambrian of South Australia: morphology, scleritome recon- 
struction and phylogeny. Acta Palaeontologica Polonica 54, 525-540. DOI 10.4202/app.2008.0082

Skovsted, C.B., BetTs, M.J., Topper, T.P. \& Brock, G.A. 2015a. The early Cambrian tommotiid genus Dailyatia from South Australia. Memoirs of the Association of Australasian Palaeontologists 48, 1-117.

Skovsted, C.B, Brock, G.A., Holmer, L. E., Topper, T.P. \& LARsson, C.M. 2015b. Revision of the Early Cambrian tommotiid Kulparina rostrata from South Australia. Journal of Paleontology 89, 920-932. DOI 10.1017/jpa.2016.5

Skovsted, C.B., Brock, G.A., Paterson, J.R., Holmer, L.E. \& BuDD, G.E. 2008. The scleritome of Eccentrotheca from the Lower Cambrian of South Australia: lophophorate affinities and implications for tommotiid phylogeny. Geology 36, 171-174. DOI 10.1130/G24385A.1

Skovsted, C.B., Brock, G.A., Topper, T.P., Paterson, J.R. \& Holmer, L.E. 2011. Scleritome construction, biofacies, biostratigraphy and systematics of the tommotiid Eccentrotheca helenia sp. nov. from the early Cambrian of South Australia. Palaeontology 54, 253-286.

DOI 10.1111/j.1475-4983.2010.01031.x

Skovsted, C.B., Holmer, L.E., Larsson, C.M., Högström, A.E.S., Brock, G.A., Topper, T.P., Balthasar, U., Petterson Stolk, S. \& Paterson, J.R. 2009b. The scleritome of Paterimitra: an Early Cambrian stem group brachiopod from South Australia. Proceedings of the Royal Society of London B 276, 1651-1656. DOI 10.1098/rspb.2008.1655

Stein, M. \& Peel, J.S. 2008. Perissopyge (Trilobita) from the lower Cambrian (Series 2, Stage 4) of North America and Greenland. GFF 130, 71-78. DOI 10.1080/11035890801302071

Sun, Y. \& BALIŃSKI, A. 2008. Silicified Mississippian brachiopods from Muhua, southern China: Lingulids, craniids, strophomenids, productids, orthotetids, and orthids. Acta Palaeontologica Polonica 53, 485-524.

DOI 10.4202/app.2008.0309
TAYloR, D.P., Vinn, O. \& Wilson, M.A. 2010. Evolution of biomineralization in "lophophorates". Special Papers in Palaeontology 84, 317-333.

Ushatinskaya, G.T. 1987. Neobychnye bezzamkovye brakhiopody iz nizhnego kembriya Mongolii. [Unusual inarticulate brachiopods from the Lower Cambrian of Mongolia.] Paleontologicheskii zhurnal 2, 62-68.

Vinn, O. \& Mutvei, H. 2009. Calcareous tubeworms of the Phanerozoic. Estonian Journal of Earth Sciences 58, 286-296. DOI 10.3176/earth.2009.4.07

YANG, X., VinN, O., Hou, X. \& Tian, X. 2013. New tubicolous problematic fossil with some "lophophorate" affinities from the Early Cambrian Chengjiang biota in south China. GFF 134, 1-7. DOI 10.1080/11035897.2013.801035

Zabini, C., Schiffbauer, J.D., XiaO, S. \& Kowalewski, M. 2012. Biomineralization, taphonomy, and diagenesis of Paleozoic lingulide brachiopod shells preserved in silicified mudstone concretions. Palaeogeography, Palaeoclimatology, Palaeoecology 326-328, 118-127.

DOI 10.1016/j.palaeo.2012.02.010

Zhang, Z., Holmer, L.E., Skovsted, C.B., Brock, G.A., Budd, G.E., Fu, D., Han, J., Wang, H., Butler, A. \& Li, G. 2013. A sclerite-bearing stem group entoproct from the early Cambrian and its implications. Scientific Reports 3, Article 1066. DOI 10.1038/srep01066

Zhang, Z., Li, G., Holmer, L.E., Brock, G.A., Balthasar, U., Skovsted, C.B., Fu, D., Zhang, X., Wang, H., Butler, A., Zhang, Z., CAO, C., Han, J., LiU, J. \& Shu, D. 2014. An early Cambrian agglutinated tubular lophophorate with brachiopod characters. Scientific Reports 4, Article 4682. DOI 10.1038/srep04682

Zhuravlev, A.Y., Wood, R.A. \& Penny, A.M. 2015. Ediacaran skeletal metazoan interpreted as a lophophorate. Proceedings of the Royal Society B 282, 20151860.

DOI $10.1098 / \mathrm{rspb} .2015 .186$ 